\title{
船 舶內のゴキブリ類
}

Cockroaches in oversea vessels

\author{
朝比奈 正二郎” ${ }^{2}$ 三原 実 \\ Syoziro Asahina \& Minoru Mihara
}

\section{はしがき}

住宅内の睆生害虫として知られているゴキブり類は, 文外航内航の船舶内の豐虫として, 旧くから注目されて いる. 住家性の有害ゴキブリ類は此較的近年のうちに世 界にひろがつたもので今日ではその大多数のものがほと んど全世界共通種となりつ〉あり，而もとの伝播には船 舶が最大の役割を果していることは疑いのない所であ る.逆にまた往時の船船による交通の事情をしらべるこ とによつて世界共通種と化したゴキブリ類の原産地をつ きとめることも試みられている(Rehn, 1945).

我が国の家住性ゴキブリ中にはその中に土着のるのる 含まれるが, 大多数は外来性のものと考劣られる.しかし その渡来の径路を特に論じたものは筆者の小報 (1955)以 前には認められない。最近大阪検疫所の人見勝氏(1956) は神戸港に於て，約 2 カ年にわたり実施した内外航路の 多数の船舶内のゴキブリ類の調査の結果を, 非公式印刷 物によつて発表され，特にチヤバネゴキブリに関する詳 細なる調査を記述して扣られる。

当研究室に於ては東洋燻蒸株式会社の宇尾五郎氏の御 希望と絶えざる御配慮によつて, 1955 年 2 月より最近に 至る約 2 年間に, 主として大阪港に於て, 28 隻以上の主 に本邦所属外航船から採集された資料を検することが出 来たので, 取敢えずこつにその結果を報ずることとした $\cdots$

冒頭に当つてこの調查のきつかけを作られた戸沢信義 氏，長期にわたつて資料を和送り下さつた宇尾五郎氏及 び東洋燻蒸㧣式会社の三宅利雄氏並びに担当の諸氏に深 く感謝の意を表するものである.

\section{調查結果及びその考察}

調查の結果は概略第 1 表に示す通り大部分本邦所属貨

1）本稿の要旨は，1956 年 11 月 23 日，衞生動物学会 東目本支部大会で講演した。

2）国立予防衛生研究所衞生昆虫部

Dep. of Medical Entomology, National Institute of Health, Tokyo
物船であり，2隻の外国船から得られたものとの特別な 差別はない様に思われる。船の大きさは分明した限りで は12,500屯から2,577屯をでのもので, 日本を中心とし て太平洋印度洋航路のものが主であり，積得む多岐に亘 うている.

送附されたゴキブリの標本は最少の場合は 1 頭, 多く の場合は概ね 10 頭位で，一と先ずこれらを，種類を知 るべき質的な資料として考光たい。

種名はチナバネゴキブリ(Blattella germanica Linné), ワモンゴキブリ(Periplaneta americana Linné)， グロゴ キブリ(Periplaneta fuliginosa Serville)の 3 種で

$\begin{array}{lr}\text { キヤバネゴキブリのみ見出された船 } & 19 \\ \text { ワモンゴキブリのみ採され集された船 } & 1 \\ \text { クロゴキブリのみ採集された船 } & 4 \\ \text { キヤバネゴキブリとワモンゴキブリ } & 4\end{array}$

となる.これらのゴキブリの種類と航路や積荷の種類と は直接の関係はない様に思われる. 之を要するに本邦の 貨物船に於ては沉世界種であるチャバネゴキブリが普通 で压倒的に多く，それに典熱寡熱帯性のワモンゴキブリ と北アメリカ南部と日本を主として極東の暖带に廒する クロゴキブリが混じていることが分つた。

以上を人見氏の調查された結果と比較すると，人見氏 が採集記録されたコワモンゴキブリ（Periplaneta australasiae Fabricius)，イェゴキブリ (Stylopyga rhombifolia Stoll)，ハイイロゴキブリ (Nauphoeta cinerea Olivier)，オガサワラゴキブリ(Leucophaea surinamensis Linné) は全くみとめられない.このことは恐らく、コ ワモンゴキブリを除いて他の 3 種はすべて船艙内からと

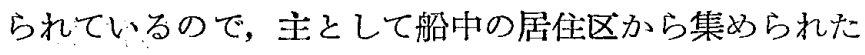
吾々の材料とは自ら相違することになつたのであらう。

次に人見氏の認めて招られないクロゴキブリが 4 例見 られることも注目すべきであるが，この種が本邦南半部 にひろく分布していることから，船内に侵大しているこ とは決して不思議でない。

次に従来本邦に産する記録もあり，又開港場の附近で 採れるといらトウヨウゴキブリ(Blatta orientalis Linné), “ジキブリBlatta concinna”の 2 種が人見氏にも吾々 
第 1 表

\begin{tabular}{|c|c|c|c|}
\hline $\begin{array}{l}\text { 採集 } \\
\text { 年月日 }\end{array}$ & 路* & 取 摭 品 物 & 重類 \\
\hline 1955 & & & \\
\hline 2. 4 & 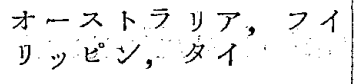 & $\begin{array}{l}\text { 羊毛, 鉱石, 米, } \\
\text { 塩, 雑貨 }\end{array}$ & $\mathrm{G}$ \\
\hline 2. 10 & 内陫，仁川 & 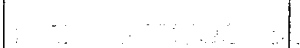 & $\mathrm{G}$ \\
\hline 2. 11 & $= \pm-\exists-\eta$ & & $G$ \\
\hline 2. 12 & 内地，吉湾 & 米, 雑貨 & G \\
\hline 2. 14 & 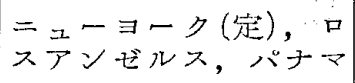 & 砂糖；小麦，“雑貨 & G \\
\hline 2. 14 & フイッッピン & $\begin{array}{l}\text { セメント, 木材, } \\
\text { 雑貨 }\end{array}$ & G \\
\hline 2. 19 & $\begin{array}{l}\text { インド(完)ママドラス, } \\
\text { シンガポール }\end{array}$ & & $\mathrm{G}, \mathrm{A}$ \\
\hline 2. 21 & ペルシヤ(定), 内地 & 重油, ガソリン & $\mathrm{G}$ \\
\hline 3. 9 & $\begin{array}{l}\text { インド，バキスタン， } \\
\text { アメリカ }\end{array}$ & ピッチ・ークス & G \\
\hline 3. 11 & フィリッピン (䂞) & 木材 & $\mathrm{G}$ \\
\hline 3. 14 & 沖繩 (定)，内地 & 雑貨 & G \\
\hline 3. 24 & 台湾 & 雑貨, バナナ & $\mathrm{G}, \mathrm{A}$ \\
\hline 4. 11 & ジャバ & ニプラ, 砂糖, 雑貨 & $\mathrm{G}, \mathrm{A}$ \\
\hline 4. 17 & バンコック, フィリッ & 米, 雑貨，木材 & $\mathrm{G}$ \\
\hline 5.18 & 内地のみ … & 染倠貨 …… & G \\
\hline 6. 10 & 内地のみ & 木材 & G \\
\hline 7. 17 & $\begin{array}{l}\text { 内地, ラングーン } \\
\text { ショック }\end{array}$ & 米, 木材 & G \\
\hline 7. 29 & $\begin{array}{l}\text { ラングーン，フィリッ } \\
\text { ピン }\end{array}$ & 米, 木材 & G \\
\hline 8. 20 & アメリガ, 朝焦 $\left(\right.$ 不 ${ }^{1}$ & 雑貨，木材 & $F$ \\
\hline 10. 16 & 日本, ペシャ (定) & 重油,ガソリン & $\mathrm{F}$ \\
\hline 10. 22 & 西アフリカ & 雑貨 & $\mathrm{F}$ \\
\hline 11. 10 & 印度，パキスタン & $\begin{array}{l}\text { 綿, フスマ,雑貨, } \\
\text { 木材 }\end{array}$ & $\mathrm{G} ; \mathrm{A}$ \\
\hline 12. 11 & ペルシャ，日本 (定) ${ }^{25}$ & $\begin{array}{l}\text { 綿, } \\
\text { 雑貨 }\end{array}$ & G \\
\hline $\begin{array}{l}1956 \\
2.22\end{array}$ & アフリカ, 南米 (定) & 穀類, 杂隹貨 & G \\
\hline 3. 4 & $\begin{array}{l}\text { 中共, フィッッ (不) } \\
\text { ピソ }\end{array}$ & 石炭，鉄鉱，木材 & G \\
\hline 3. 16 & オーストラリア …(定) & 雑貨 & G \\
\hline 6. 21 & 中近東, 南米 “不) & 綿, 雑貨, 米 & $A$ \\
\hline 10. & 印度，パキスタン(定) & 綿, 雑貨, 塩 & $\mathrm{F}$ \\
\hline
\end{tabular}

（註） * (定)=定期船，（不）二不定期船

** $\mathrm{G}=$ Blattella germanica $\mathrm{L}$.

$\mathbf{A}=$ Periplaneta americana $\mathbf{L}$.

$\mathrm{F}=$ Periplaneta fuliginosa $\mathrm{S}$.

1）韓国船 2) 外国船国籍不明
のにあ認められないことは，これらの種の本邦に於ける 分布を大いに颖わしむる資料であると思 5 .

曾て昆虫世界の紙上で，“船中の害虫之帝国の耻摩”, という題のもとに田中節三郎という人の通信文の一節 がのせられたことがあるが，抄出すると、“東洋通い の外国汽船にては，木大此虫の生存を目軗せ乙事無之， その陮駆除の行届けるには，笑に感心の至りに候.之 に反して，本邦人の害虫駆除に冷淡なるは，社会一般の 通然にて，堂々たる汽船内にも此かる珍事有之，彼我相 違の甚たしきに警大り，書虫に対する観察の深からざる は，唯り農家のみには無之義と存居候. 仗兄荷物塔載船 とは由乙作ら，斯る大会社の船室に，婦女子の最とも忌

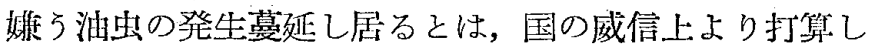
て，如何にも残念至極に御座侯”ということで，この 记事の明治 35 年 (1902) より以後既に半世紀をこえた今 日でも鿖未だジキブリ類が，特に本邦船船中に限つて (?)跳梁しているということは大い洘えなければなら ないことふ思う次第である。

\section{参考文献}

1）朝比奈正二郎 (1955)：家任性ゴキブッと之の分 布. 龦生動物, 6(4): 39. - -2) 朝比奈正二郎 (1956) : 衞生昆虫としての邦座ゴキブリの種類. 衞生動物, $7(2): 134$. - 3) 人見勝 $(1956)$ ：船船内に於けるゴ キブリ類. 特にチャバネゴキブりの棲息実態に就い て, 第 1 号. 大阪袷度所謄写印刷物, pp. 11. 3 表. -4) Rehn, J. A. G. (Oct. 1945) : Man's uninvited fellow traveller, the cockroach. Sci. Month., 265-276. 一-5) 时中節三郎(通信) (1902)：船中 の害虫已帝国の恥辱. 昆虫世界，6(63)：476-477.

\section{Summary}

The eradication of the cockroaches established in the ships sailing home and abroad is a great concern for the sanitary officers. The result of a survey practised for about two years at Kobe herbour, of the species of the cockroaches taken from 28 steamboats was presented in this paper. The material, each a small example of cockroaches collected by fumigation has been sent for identification to our laboratory.

The most prevailing species was the German roach, Blattella germanica, being found in 23 ships; the other two species, the American roach, Periplaneta americana, and our common black roach, $P$. fuliginosa were taken in five and four cases respectively. 